Original Research Paper

\title{
Pelatihan Preparasi Kromosom dan Analisis Karyotipe Pada Dosen-Dosen Biologi di Universitas Nahdlatul Wathan Mataram
}

\author{
I Gde Mertha $^{1 *}$, Agil Al Idrus ${ }^{1}$, Ahmad Raksun ${ }^{1}$, I Wayan Merta ${ }^{1}$, Syamsul Bahri ${ }^{1}$ \\ ${ }^{1-5}$ Biology Education, University of Mataramy, Indonesia;
}

https://doi.org/10.29303/jpmpi.v3i2.1162

Sitasi: Mertha, I. G., Idrus, A. A., Raksun, A., Mertha, I. W \& Bahri, S. (2021). Pelatihan Preparasi Kromosom dan Analisis Karyotipe Pada Dosen-Dosen Biologi di Universitas Nahdlatul Wathan Mataram. Jurnal Pengabdian Magister Pendidikan IPA 4(4)

\section{Article history}

Received: 10 Oktober 2021

Revised: 30 Oktober 2021

Accepted: 17 November 2021

*Corresponding Author: I Gde Mertha, University of Mataram, Mataram, Indonesia; Email:

gdemertha19@gmail.com
Abstrak: Dalam upaya untuk meningkatkan kompetensi dosen di bidang penelitian diperlukan keterampilan, pengalaman dan kemampuan dasar yang kuat dalam metode dan teknik-teknik penelitian yang senantiasa berkembang dari waktu ke waktu. Dengan demikian perlu bagi seorang dosen untuk selalu mengikuti perkembangan teknik-teknik penelitian baru serta tukar pengalaman diantara sesama terutama pada pakar yang berhubungan dengan keilmuannya. Kegiatan pengabdian ini telah dilaksanakan di Universitas Nahdlatul Wathan Mataram. Tujuan pengabdian ini adalah meningkatkan wasasan dan keterampilan dosen-dosen biologi melalui pendamping praktikum agar dapat membuat preparat squash untuk pengamatan struktur dan morfologi kromosom metafase, penyusunan karyogram, dan analisis karyotipenya. Kegiatan pelatihan ini dilakukan dengan menggunakan beberapa metode, yaitu ceramah, tanya jawab, diskusi, dan unjuk kerja berupa kegiatan praktik, yang selanjutnya dilakukan refleksi dan evaluasi. Kegiatan praktik yang dilakukan, yaitu (a) praktik mikroteknik pembuatan preparat squash kromosom, (b) praktik identifikasi struktur dan morfologi kromosom dibawah mikroskop, (c) praktik pengambilan foto struktur dan morfologi kromosom dibawah mikroskop, (d) praktik penyusunan karyogram kromosom metafase, dan (e) praktek analisis karyotipe kromosom. Berdasarkan hasil evaluasi terhadap kegiatan pengabdian ini dapat disimpulkan sebagai berikut: (1) Pengabdian ini memberikan pengalaman sangat bermanfaat tentang teknik pembuatan preparat untuk pengamatan morfologi kromosom, teknik dokumentasi kromosom dibawah mikroskop dan pengukuran parameter dalam analisis karyotipe, (2) Motivasi yang tinggi dosen mitra sangat menunjang keberhasilan pembuatan preparat kromosom dan analisis karyotipe dalam pelatihan ini, dan (3) Pengetahuan dan keterampilan yang diperoleh dosen mitra merupakan bekal ipteks berbasis kromosom yang sangat berhaga untuk kegiatan perkuliahan dan penelitian.

Kata kunci: analisis karyotipe, kromosom, preparat squash

\section{Pendahuluan}

D osen adalah pendidik profesional/ilmuwan dengan peran utama mentransformasikan, mengembangkan, serta menyebarluaskan ilmu pengetahuan dan teknologi melalui tridarma perguruan tinggi. Tugas dosen antara lain (1) melaksanakan pembelajaran yang dapat meliputi perkuliahan, seminar, diskusi, praktikum, simulasi dan evaluasi, (2) melaksanakan pembimbingan kepada mahasiswa atas penyelesaian tugas akhir dan 
tugas-tugas akademik lainnya, (3) meningkatkan dan mengembangkan kualifikasi akademik dan kompetensi secara berkelanjutan, dan (4) melakukan penelitian dan pengembangan karya ilmiah dengan melakukan riset sesuai tuntutan perkembangan ilmu pengetahuan dan teknologi.

Perkembangan ilmu pengetahuan dan teknologi yang sangat pesat menuntut dosen untuk mengimbangi perubahan yang terjadi. Perubahan zaman menutut semua hal untuk berubah, termasuk kompetensi dosen sebagai pendidik di perguruan tinggi yang akan menghasilkan calon sumber daya manusia Indonesia. Sebagai orang yang akan bertanggung jawab menghasilkan calon sumber daya manusia ini, diharapkan dosen harus memiliki kompetensi terlebih dalam menghadapi era revolusi industry 4.0. Dosen harus senantiasa belajar dan berbenah diri menyesuaikan kompetensinya dengan zaman agar mampu tetap eksis menjadi dosen yang memberikan pengetahuan masa depan bukan masa lalu (Rusmana, 2019). Oleh sebab itu agar tidak tertinggal zaman dan ditinggalkan zaman, dosen harus terus meningkatkan kompetensinya, misalnya dengan mengadakan penelitian dan ikut pelatihan agar selalu update ilmu pengetahuan dan teknologinya.

Penelitian yang dikembangkan dosen harus inovatif dan didukung ilmu teknologi terkini. Hasil penelitian akan layak publikasi salah satu kriteria apabila ditunjang penggunaan teknik-teknik riset yang update. Dengan demikian sangat penting bagi dosen untuk selalu mengikuti perkembangan teknikteknik penelitian dengan banyak melakukan kerjasanma dengan berbagai kampus terutama pakar yang berhubungan dengan keilmuannya.

Salah satu teknik penelitian yang mengalami inovasi baru dalam preparasinya adalah pembuatan preparat kromosom (Singh, 1993; Mertens dan Hammersmith, 2001). Kromosom adalah sekumpulan gen (DNA) dalam inti sel yang berperan dalam pewarisan sifat keturunan (Kirpichnikov, 1981; Tave, 1986; Pai, 1987; Suryo, 1996) dalam Sucipto
(2012). Teknik preparasi kromosom terus berkembang dari waktu ke waktu sehingga sampai saat ini sudah banyak mengalami modifikasi. Perubahan teknik dalam pembuatan preparat kromosom non banding dengan metode squash, antara lain pada modifikasi pewarnaan (Mertha, 2001; Mertens dan Hammersmith, 2001; Mertha et al., 2019). Pewarna untuk kromosom non banding yang umum digunakan adalah aceto orcein atau aceto carmin (Darlongton dan La Cour, 1960; Soerodikoesoemo, 1987). Hasil penelitian terbaru telah digunakan pewarna lain, misalnya carbol fuchsin, shift reagen, dan carbolic fuchsin (Prakash, 1986; Jahier et al., 1996, Mertha, 2001). Selain penggunaan pewarna terbaru, teknik hidrolisis dan pra perlakuan juga banyak mengalami penyesuaian (Jahier et al., 1996; Mertha, 2001). Dengan teknik terbaru, dihasilkan gambaran morfologi kromosom yang jelas dengan warna yang lebih kontras. Selain itu, sebaran krmosom lebih baik (tidak tumpang tindih) sehingga memudahkan dalam penyusunan diagram karyotipe berupa karyogram baik secara manual maupun dengan aplikasi komputer.

Kromosom yang telah disusun dalam karyogram merupakan karyotipe sumber data penelitian yang penting dalam riset bahan genetik. Penyusunan karyotipe dilakukan dengan cara mengurutkan pasangan kromosom dari ukuran terbesar sampai terkecil berdasarkan kehomologan bentuk dan ukuran. Agar memiliki nilai sebagai data penelitian karyotipe perlu dianalisis. Analisis karyotipe terutama ditekankan pada variasi panjang lengan kromosom, variasi panjang total komplemen haploid kromosom, indeks asimetri, variasi bentuk dan struktur kromosom, klasifikasi kromosom, dan rumus karyotipe (Sharma, 1976; Sivarajan, 1984). Hasil analisis karyotipe sangat diperlukan pada kajian sitogenetika dan sitotaksonomi, misalnya sebagai petunjuk proses evolusi, identifikasi spesies hasil persilangan, taksonomi modern, penyimpangan genetik 
mutasi, serta variasi genetik antar populasi dalam satu spesies (Laimeheriwa, 2018).

Program studi pendidikan biologi dan program studi biologi Universitas Nahdlatul Wathan Mataram merupakan dua program studi yang masih bergiat meningkatkan mutu pendidikannya. Dalam upaya peningkatan mutu pendidikan tersebut, dosen-dosen perlu dibekali teknik preparasi kromosom dan analisis karyotipe. Namun kendala utama yang dihadapi dosen ketika akan merencanakan penelitian dan membimbing praktikum genetika dan ilmu lain yang berbasis kromosom adalah mereka belum banyak mengenal mikroteknik yang benar dalam preparasi preparat untuk pengamatan kromosom dibawah mikroskop sehingga tidak dapat menyusun karyogram, dengan demikian belum banyak memiliki pengalaman dalam analisis karyotipenya. Berdasarkan kondisi tersebut, dalam upaya meningkatkan kualitas penelitian dan pembelajaran serta untuk mengimbangi perkembangan ipteks berbasis kromosom yang terus berkembang, dosendosen biologi di Universitas Nahdlatul Wathan Mataram harus dibekali pengetahuan dan keterampilan preparasi sediaan kromosom dan penyusunan karyogram yang disesuaikan dengan kemajuan teknik inovatif. Oleh sebab itu tujuan yang diharapkan dari kegiatan pengabdian ini adalah meningkatkan wasasan dan keterampilan dosen-dosen biologi melalui pendamping praktikum untuk dapat membuat preparat kromosom, penyusunan karyogram, dan analisis karyotipenya. Sedangkan manfaat yang diharapkan dari pengabdian ini adalah bahwa kegiatan ini akan menambah kompetensi dosen biologi tentang preparasi preparat mikroskopis squash jaringan meristem untuk pengamatan kromosom dan analisis karyotipe, selanjutnya dengan penguasaan pengetahuan dan keterampilan tersebut akan meningkatkan kemampuan dosen dalam penelitian, bimbingan praktikum mahasiswa, dan bimbingan skripsi mahasiswa pada bidang ilmu yang berkakaitan dengan genetika khususnya sitogenetika dan sitotaksonomi.

\section{Metode}

Kegiatan pelatihan ini dilakukan dengan menggunakan beberapa metode, yaitu ceramah, tanya jawab, diskusi, dan unjuk kerja berupa kegiatan pelatihan praktik. Penyampaian materi pelatihan dilakukan dengan cara ceramah, diskusi dan tanya jawab. Kegiatan praktik dilaksanakan setelah penyampaian materi. Setiap peserta melakukan kegiatan praktikum mandiri. Pada saat praktik dilakukan pendampingan untuk memberikan bimbingan pada keterampilan kerja dosen-dosen biologi (dosen mitra).

Praktek preparasi preparat kromosom dan analisis karyotipenya dilakukan pada jaringan meristematik ujung akar Allium ascalonicum. Dengan dipandu petunjuk praktikum pelatihan dan bimbingan tim pengabdian, dosen mitra membuat preparat squash ujung akar. Praktek dokumentasi foto dilakukan pada kromosom metafase yang tersebar dengan baik dan tidak tumpang tindih. Karyotipe dibuat berdasarkan foto-foto kromosom yang disajikan dalam diagram sebagai karyogram. Praktik analisis karyotipe dilakukan terhadap ciri kuantitatif dan kualitatif kromosom.

Untuk meyakinkan bahwa praktek pembuatan preparat kromosom telah dilaksanakan dengan benar oleh dosen-dosen biologi (dosen mitra) maka dilakukan refleksi dan evaluasi. Pada kegiatan ini dilakukan diskusi untuk membahas kesulitan-kesulitan yang dihadapi selama praktek mikroteknik pembuatan preparat squash kromosom dan analisis karyotipe. Evaluasi keberhasilan pada pengabdian ini adalah apabila $85 \%$ target dari program ini tercapai.

\section{Hasil dan Pembahasan}

Pengabdian kepada masyarakat ini mencakup lima kegiatan pendampingan praktik yang mencakup pembuatan preparat untuk pengamatan kromosom, pengamatan morfologi kromosom metafase atau submetafase, 
pengambilan visualisasi morfologi kromosom, pembuatan karyotipe, dan analisis karyotipe. Dosen mitra menunjukkan minat yang tinggi terhadap materi praktikum yang disampaikan tim pengabdian yang terlihat dari keseriusan mengikuti pelatihan ini. Berdasarkan hasil refleksi dan evaluasi bahwa lebih dari 85\% target dari program ini tercapai. Luaran pelatihan yang dihasilkan pada masing-masing kegiatan praktikum adalah preparat squash ujung akar, keterampilan menentukan jumlah dan bentuk morfologi kromosom, visualisasi foto morfologi kromosom, diagram kromosom atau karyogram yang disusun berdasarkan jumlah dan morfologi pasangan kromosom, dan pengetahuan dan pengalaman analisis sifat kuantitatif dan kualitatif kromosom sebagai data penelitian.

\section{Pembuatan preparat kromosom}

Preparasi preparat kromosom dilakukan dosen mitra dalam sepuluh langkah praktikum sesuai petunjuk Mertha (2001). Kegiatan pembuatan preparat untuk pengamatan kromosom mencakup pengambilan cuplikan jaringan meristem, pra perlakuan, fiksasi, hidrolisis, pewarnaan, pemencetan (squashing), penyegelan, dan pemberian label. Pencucian dilakukan setelah hidrolisis dan setelah pewarnaan.

Pemotongan ujung akar menyesuaikan dengan waktu optimal mitosis sedangkan pra perlakuan digunakan kemikalia penghambat mitosis. Pengambilan ujung akar Allium ascalonicum dilakukan pada pukul 08.00-10.00 WITA. Akar dipotong sepanjang $1 \mathrm{~cm}$ dari ujung, selanjutnya diambil menggunakan kuas dan segera dimasukkan kedalam botol flakon yang berisi larutan 0,002 M 8Hidroksikuinolin. Pertanyaan yang diajukan dosen mitra pada kegiatan pra perlakuan ini: "Apa tujuan perendaman ujung akar dalam larutan 8-Hidroksikuinolin?" Jawaban tim pengabdian: "Larutan 8-Hidroksikuinolin dapat memutus benang spindel sehingga kromosom yang berada pada prometafase dan metafase tidak melanjutkan ke anafase. Kromosom yang tersebar akan tampak jelas bentuk morfologinya".

Perlakuan hidrolisis dan squashing memberi pengalaman dan keterampilan berharga pada dosen mitra. Beberapa preparat yang dibuat dosen mitra kurang bagus karena kekeliruan pada kedua langkah tersebut. Hidrolisis yang dilakukan terlalu cepat menyebabkan ujung akar masih keras sehingga menyulitkan dalam squashing. Hidrolisis yang dilakukan melebihi waktu yang ditentukan mengakibatkan antara lain hasil pewarnaan kromosom menjadi kurang jelas. Dengan semangat ingin tahu yang tinggi, dosen mitra mencoba kembali membuat preparat dengan menyesuaikan waktu hirolisis yang tepat. Hasil hidrolisis tersebut menyebabkan ujung akar menjadi lunak dan kromosom mudah menyerap warna. Ujung akar yang lunak memudahkan proses squashing. Kegiatan praktikum yang cukup banyak memerlukan pendampingan pada pelatihan ini yaitu pada saat peserta pelatihan melakukan squashing. Pengalaman awal yang dialami beberapa peserta pelatihan, bahwa pemencetan (squashing) yang dilakukan menyebabkan gelas penutup bergeser sehingga sel-sel saling bertumpang tindih (menggumpal) satu sama lain. Melalui latihan yang tekun dan berulang-ulang, peserta dapat menyebarkan sel-sel misalnya dengan cara mengetuk gelas penutup dengan ujung gagang pensil atau kuas dan melakukan squashing dengan tetap menjaga agar gelas penutup tetap berada pada posisinya. Dengan kerja keras dan pendampingan tim pengabdian, peserta pelatihan (dosen mitra) dapat membuat preparat yang baik dibuktikan sel-sel tersebar 
merata demikian pula tampilan kromosom metafase cukup baik untuk pembuatan karyotipe.

\section{Pengamatan kromosom}

Pendampingan

pengamatan

mikroskopik dilakukan tim pengabdian untuk memberikan bimbingan kepada peserta pelatihan dalam melakukan pengamatan sel-sel yang menunjukkan penyebaran kromosom yang baik. Peserta pelatihan ditugaskan untuk melakukan pengamatan sel-sel metafase dibawah mikroskop cahaya. Pencarian sel-sel yang memiliki kromosom tersebar dengan baik dilakukan pada perbesaran lemah. Setelah posisi sel yang dicari diketahui, dilanjutkan pengamatan pada perbesaran yang lebih kuat pada $400 x$ atau $1000 x$.

Pengamatan kromosom pada perbesaran 400x peserta pelatihan dapat menghitung jumlah kromosom dan menentukan gambaran bentuk kromosom. Dengan rasa ingin tahu dan anusias yang tinggi, peserta pelatihan mengamati morfologi kromosom yang ditemukan. Pada awal pengamatan, peserta pelatihan selalu meminta verifikasi tim pengabdian terhadap preparat kromosom yang diamati. Pada perbesaran 1000x peserta pengabdian dapat mengamati struktur kromosom secara lebih jelas. Kromosom yang sulit dibedakan karena lengan yang bertumpang tindih, biasanya akan lebih mudah diidentifikasi pada perbesaran kuat ini.

\section{Dokumentasi kromosom}

Visualisasi terutama dilakukan pada sel-sel yang menunjukkan penyebaran kromosom yang baik dan dengan morfologi yang jelas. Dalam satu preparat, peserta pelatihan dapat mengamati beberapa kromosom yang tersebar dengan baik yang dicirikan tidak tumpang tindih satu sama lain. Pada kromosom yang tersebar dengan baik ini, dosen mitra dapat mengamati lengan kromosom dan adanya lekukan primer yang merupakan sentromer. Kromosom Allium ascalonicum yang dihasilkan pada pelatihan ini menunjukkan kromatid saudara yang jelas yang mudah diamati peserta pelatihan.



Gambar 1. Kegiatan pengabdian di Universitas Nahdlathul Wathan Mataram. A. Pengeluaran larutan 8Hidroksikuinolin setelah selesai pra perlakuan terhadap ujung akar Allium ascalonicum. B. Penyebaran sel-sel meristem ujung akar sebelum dilakukan squashing. C. Diskusi teknik pembuatan preparat untuk pengamatan kromosom. D. Penghitungan jumlah kromosom dan pengamatan morfologi kromosom dibawah mikroskop.

Pengambilan gambar untuk visualisasi kromosm dilakukan dengan menggunakan mikroskop foto dan kamera handphone. Pada kegiatan dokumentasi ini, peserta pelatihan dapat melakukan pengambilan foto kromosom dibawah mikroskop dengan baik. Hasil perekaman dengan mikroskop foto dapat dilihat pada layar komputer dan dengan aplikasi pada komputer dapat ditentukan panjang kromosom. Dosen mitra juga diberi keterampilan memasang microscope phone holder pada tabung lensa okuler dan penempatan handphone yang tepat untuk visualisasi kromosom dibawah mikroskop. Dengan bimbingan tim pengabdian dan unjuk 
kerja, peserta pelatihan dapat mengatur jarak dan posisi handphone terhadap lensa okuler sehingga kromosom tampak jelas pada layar handphone sehingga pemotretan tepat sasaran.

\section{Penyusunan karyogram dan idiogram}

Pembentukan diagram kromosom sebagai karyogram berdasarkan foto yang diperoleh dari hasil pemotretan. Peserta pelatihan menyusun karyogram dengan cara manual dan dengan bantuan program pada komputer. Secara manual, peserta pelatihan ditugaskan untuk memotong foto kromosom sesuai bentuknya dan menentukan pasangan kromosom berdasarkan bentuk dan ukuran. Secara digital, gambar kromosom dipotong menggunakan aplikasi pada komputer dan berdasarkan bentuk dan ukuran dipasangkan dengan homolognya. Pada kedua cara tersebut, peserta pelatihan mengurutkan pasanganpasangan kromosom dari ukuran terbesar sampai terkecil dengan posisi sentromer yang berada pada satu garis lurus. Berkat partisipasi mitra yang sangat aktif dan kreatif, pembuatan peta kromosom ini berhasil dilakukan dengan benar.

Karyogram dijadikan dasar dalam pembentukan idiogram. Penyusunan idiogram ditujukan untuk memudahkan pengamatan peta kromosom. Panjang rata-rata lengan panjang dan lengan pendek pasangan-pasangan kromosom dalam karyogram yang telah dilakukan pengukuran oleh peserta pelatihan digunakan untuk pembentukan idiogram. Dengan tekun dan rasa tanggung jawab yang tinggi, peserta pelatihan mencari rata-rata panjang kromosom pada minimal tiga karyogram dan berhasil menyusun gambar skematis peta kromosom sebagai idiogram.

\section{Analisis karyotipe}

Analisis karyotipe meliputi penentuan sifat kuantitatif dan kualitatif kromosom. Penentuan parameter kuantitatif dalam analisis karyotipe telah dilakukan peserta pengabdian dengan mengacu Mertha (2001) yang mencakup jumlah kromosom, penentuan panjang lengan kromosom, panjang absolut kromosom dan rasionya, panjang total komplemen haploid kromosom, indeks asimetri kromosom dan proporsi kromosom dengan rasio lengan lebih besar dari 2,0. Berdasarkan data kuantitatif, peserta pelatihan dapat menentukan bentuk dan struktur kromosom, rumus karyotipe, serta klasifikasi karyotipe.

Pengetahuan dan keterampilan analisis karyotipe yang diperoleh dosen mitra merupakan pengalaman sangat bermanfaat untuk menunjang kegiatan penelitian dan pengajaran. Hasil analisis karyotipe sangat penting pada penelitian genetika dan ilmu lain berbasis kromosom, misalnya pada kajian sitogenetika dan sitotaksonomi.

\section{Kesimpulan}

Berdasarkan hasil evaluasi terhadap kegiatan pengabdian ini dapat disimpulkan sebagai berikut: (1) Pengabdian ini memberikan pengalaman sangat bermanfaat tentang teknik pembuatan preparat untuk pengamatan morfologi kromosom, teknik dokumentasi kromosom dibawah mikroskop dan pengukuran parameter dalam analisis karyotipe, (2) Motivasi yang tinggi dosen mitra sangat menunjang keberhasilan pembuatan preparat kromosom dan analisis karyotipe dalam pelatihan ini, dan (3) Pengetahuan dan keterampilan yang diperoleh dosen mitra merupakan bekal ipteks berbasis kromosom yang sangat berhaga untuk kegiatan perkuliahan dan penelitian.

\section{Ucapan Terima Kasih}


Terima kasih kepada LPPM Universitas Mataram yang telah memberi kesempatan kegiatan pengabdian kepada masyarakat ini. Terimakasih disampaikan kepada Universitas Nahdlathul Wathan Mataram atas kerjasamanya sehingga pengabdian ini dapat terlaksana dan berjalan lancar.

\section{Daftar Pustaka}

Darlington, C.D. dan L. F. La Cour, 1960. The Handling of Chromosomes. George Allen \& Unwin Ltd. London.

Jahier, J., A.M. Chevre, F. Eber, R. Delourne, dan A.M. Tanguy. 1996. Technique of Plant Cytogenetics. Science Publishers, Inc., Lebanon.

Jones, R.N. dan C.K. Rickards. 1991. Practical Genetics. John Wiley \& Sons, New York.

Laimeheriwa, B. M. 2018. Sitogenetika dan Analisis Kromosom. Patimura University. Ambon.

Mertens, T.R. dan R. L, Hammersmith. 2001. Genetics Laboratory Investigations. Twelfth Edition. Princte Hall. Upper Saddle River. New Jersey.

Mertha, I.G. 2001. Taksonomi Murraya exotica L. dan Murraya paniculata (L.) Jack. di Jawa: Suatu Pendekatan Berdasarkan Karyotipe. Jurnal Biologi Tropis 2(2).

Mertha, I.G., A. Al Idrus, S. Bahri, P. Sedijani, dan D.A.C. Rasmi. 2019. Pelatihan teknik pembuatan preparat squash ujung akar untuk pengamatan kromosom pada guru-guru biologi di Kota Mataram. Jurnal Pendidikan dan Pengabdian Masyarakat, November 2019, Vol. 2, No. 4: $454-459$.

Prakash, 1986. Method in Plant Microtechnique. Departement of Botany. The University of New England. Armidale, N.S.W.
Rusmana, F. D. 2019. Dosen di Era revolusi Industry 4.0. STEI Al-Amar Subang. Jawa Barat.

Sharma, 1976. The Chromosome. Oxford \& IBH Publishing Co. New Delhi.

Singh, R.J. 1993. Plant Cytogenetic. CRC Press, London.

Sivarajan, V.V. 1984. Introduction to Principles of Plant Taxonomy. Oxford $\&$ IBH Publishing Co., New Delhi.

Soerodikoesoemo, W. Petunjuk Praktikum Mikroteknik Tumbuhan. Lab. Embriologi \& Mikroteknik Tumbuhan. Fakultas Biologi. Universitas Gadjah Mada. Yogyakarta.

Sucipto, A. 2012. Kromosom dan Karyotipe pada Ikan. https://www.adisucipto.com/kromoso m-dan-karyotipe-ikan. 